\title{
Analysis of methylation of antioxydant-related genes in patiens with common cardio- and cerebrovascular diseases
}

\author{
Olga Bushueva \\ KSMU, Kursk, Russia \\ olga.bushueva@inbox.ru \\ Yulia Koroleva \\ RIMG, TNRMC RAS \\ Tomsk, Russia \\ yuliya.koroleva@medgenetics.ru \\ Alexey Polonikov \\ KSMU, Kursk, Russia \\ polonikov@rambler.ru
}

\author{
Ekaterina Barysheva \\ KSMU, Kursk, Russia \\ ekatbarysheva@yandex.ru \\ Egor Churkin \\ RIMG, TNRMC RAS \\ Tomsk, Russia \\ anton.markov@medgenetics.ru \\ Vladimir Ivanov \\ KSMU, Kursk, Russia \\ ivanovvp@kursksmu.net
}

\author{
Anton Markov \\ RIMG, TNRMC RAS \\ Tomsk, Russia \\ anton.markov@medgenetics.ru \\ Maria Nazarenko \\ RIMG, TNRMC RAS \\ Tomsk, Russia \\ maria.nazarenko@medgenetics.ru
}

\begin{abstract}
It is well-known that oxidative stress may contribute to the increased risk of cardio- and cerebrovascular diseases. The aim of our study was to analyze the level of methylation of antioxidant-related genes (MPO, TXNRD1, $G C L M, G S T P 1)$ in patients with coronary artery disease $(\mathrm{N}=45)$, cerebral stroke $(\mathrm{N}=30)$ and healthy controls $(\mathrm{N}=83)$. DNA methylation level was evaluated by bisulfite pyrosequencing. Analysis of coronary artery disease revealed a significant decrease in methylation level for all genes, however, the most significant differences were found for $\operatorname{GCLM}\left(\mathrm{P}=3.63 \times 10^{-8}\right)$ and MPO $\left(\mathrm{P}=3.83 \times 10^{-7}\right)$. An analysis of cerebral stroke revealed decrease in methylation levels in all genes except TXNRD1; the most significant differences were observed for GSTP1 $\left(\mathrm{P}=9.43 \times 10^{-6}\right)$ and $M P O\left(\mathrm{P}=5.25 \times 10^{-11}\right)$. Molecular-genetic and epigenetic mechanisms of the involvement of redox-homeostasis genes in the development of common cardio- and cerebrovascular diseases are discussed.
\end{abstract}

Keywords - oxidative stress, DNA methylation, coronary artery disease, cerebral stroke

\section{Motivation and Aim}

Cardio- and cerebrovascular diseases (CCVD) is the most common cause of morbidity and mortality worldwide. Previous investigations have found that oxidative stress may contribute to the increased risk of CCVD via a variety of mechanisms, including endothelial dysfunction, smooth muscle cell contraction, inflammatory process, lipid peroxidation, activation of metalloproteinases etc [1]. It is noteworthy that epigenetic studies of genes involved in regulation of vascular redox homeostasis are single.

The aim of the study was to analyze weather the methylation of antioxidant-related genes may contribute to the increased risk of coronary artery disease and cerebral stroke.

\section{Methods}

Genomic DNA was isolated from their peripheral blood leukocytes. Then, bisulfite DNA conversion was performed. To assess the status of DNA methylation, the promoter regions of the TXNRD1 genes (3 CpG-sites), GSTP1 (2 CpG-sites), GCLM (4 CpG-sites), and 4-6 exons of the MPO gene (3 CpGsites) were selected. DNA methylation status was determined in the blood leukocytes of healthy individuals $(\mathrm{N}=83)$ and patients with common cardio- and cerebrovascular diseases (coronary artery disease $(\mathrm{N}=45)$ and cerebral stroke $(\mathrm{N}=30)$ ). All patients with coronary artery disease $(\mathrm{CAD})$ and cerebral strike (CS) had a history of arterial hypertension. DNA methylation level was evaluated by bisulfite pyrosequencing using a PyroMark Q24 (Qiagen). To compare the methylation level of CpG-sites, the Mann-Whitney $U$ test was used in SPSS Statistics v23.

\section{Results}

A comparative analysis of the methylation level revealed pronounced differences between CVD patients and healthy individuals. Analysis of coronary artery disease revealed a significant decreasing in methylation level for all genes, however, the most significant differences were found for $\operatorname{GCLM}\left(\mathrm{P}=3.63 \times 10^{-8}\right)$ and $M P O\left(\mathrm{P}=3.83 \times 10^{-7}\right)$. An analysis of cerebral stroke revealed decrease in methylation levels in all genes except TXNRD1; the most significant differences were observed for GSTP1 $\left(\mathrm{P}=9.43 \times 10^{-6}\right)$ and $M P O\left(\mathrm{P}=5.25 \times 10^{-11}\right)$ (Table 1).

Table 1 - A comparative analysis of methylation of genes (the region average value) in patients with various cardiovascular phenotypes and in healthy controls

\begin{tabular}{|c|c|c|c|c|c|}
\hline \multicolumn{2}{|c|}{ Genes } & Control & CAD & Control & $\mathrm{CS}$ \\
\hline \multirow[t]{2}{*}{ GSTP1 } & $\begin{array}{c}\mathrm{Me} \\
(\mathrm{Q} 0,25 \\
-0,75)\end{array}$ & $\begin{array}{c}4.3 \\
{[3.5 ; 6.7]}\end{array}$ & $\begin{array}{c}3.6 \\
{[2.6 ; 5.7]}\end{array}$ & $\begin{array}{c}4.4 \\
{[3.6 ; 7.1]}\end{array}$ & $\begin{array}{c}2.7 \\
{[2.3 ; 3.9]}\end{array}$ \\
\hline & $P_{\text {adj }}$ & \multicolumn{2}{|c|}{$0.01 *$} & \multicolumn{2}{|c|}{$9.43 \times 10^{-6^{*}}$} \\
\hline \multirow[t]{2}{*}{$G C L M$} & $\begin{array}{c}\mathrm{Me} \\
(\mathrm{Q} 0,25 \\
-0,75)\end{array}$ & $\begin{array}{c}7.8 \\
{[5.3 ; 10.1]}\end{array}$ & $\begin{array}{c}3.4 \\
{[2.7 ; 4.7]}\end{array}$ & $\begin{array}{c}7.9 \\
{[5.3 ; 10.3]}\end{array}$ & $\begin{array}{c}5.8 \\
{[4.1 ; 7.1]}\end{array}$ \\
\hline & $P_{\text {adj }}$ & \multicolumn{2}{|c|}{$3.63 \times 10^{-8^{*}}$} & \multicolumn{2}{|c|}{$0.004 *$} \\
\hline \multirow[t]{2}{*}{ TXNRD1 } & $\begin{array}{c}\mathrm{Me} \\
(\mathrm{Q} 0,25 \\
-0,75)\end{array}$ & $\begin{array}{c}4.0 \\
{[3.0 ; 5.2]}\end{array}$ & $\begin{array}{c}3.1 \\
{[2.5 ; 3.7]}\end{array}$ & $\begin{array}{c}4.1 \\
{[3.0 ; 5.2]}\end{array}$ & $\begin{array}{c}4.2 \\
{[3.0 ; 5.5]}\end{array}$ \\
\hline & $\mathrm{P}_{\mathrm{adj}}$ & \multicolumn{2}{|c|}{$0.0002 *$} & \multicolumn{2}{|c|}{0.78} \\
\hline \multirow[t]{2}{*}{$M P O$} & $\begin{array}{c}\mathrm{Me} \\
(\mathrm{Q} 0,25 \\
-0,75)\end{array}$ & $\begin{array}{c}35.4 \\
{[30.3} \\
42.6]\end{array}$ & $\begin{array}{r}26.5 \\
{[24.5} \\
32.3]\end{array}$ & $\begin{array}{l}35.6 \\
{[30.4} \\
42.6]\end{array}$ & $\begin{array}{c}24.3 \\
{[19.8} \\
27.8]\end{array}$ \\
\hline & $P_{\text {adj }}$ & \multicolumn{2}{|c|}{$3.83^{*} 10^{-7^{*}}$} & \multicolumn{2}{|c|}{$5.25^{*} 10^{-11^{*}}$} \\
\hline $\begin{array}{l}P_{\text {adj }}-P-l e v \\
\text { Note: } \text { Bol }\end{array}$ & ter ad. & ent for $n$ & ple com & ons; & \\
\hline
\end{tabular}

However, DNA methylation levels of studied genes, except $M P O$, varied within low ranges (\% of methylated cytosines $<10 \%$ ). Analyzed region of $M P O$ is located in $\mathrm{CpG}-$ island, and according to JASPAR database, contains motifs for several transcription factors (E2F6, TFDP1, NHLNH2, 
and others). ChIP-seq based data from ENCODE strongly supports existence of E2F6 binding site, which could be impaired by abnormal DNA methylation in blood cells of patients with CCVD.

\section{Conclusion}

We found significant differences in the level of DNA methylation of redox-homeostasis genes between healthy individuals and patients with common cardio- and cerebrovascular disease (coronary heart disease and cerebral stroke).

\section{REFERENCES}

[1] Incalza, Maria Angela, et al. (2018) Oxidative stress and reactive oxygen species in endothelial dysfunction associated with cardiovascular and metabolic diseases. Vascular pharmacology. 100 (2018): 1-19. 